DOI 10.22460/infinity.v7i2.p97-108

\title{
THE EFFECTIVENESS OF PROBLEM-BASED LEARNING WITH SOCIAL MEDIA ASSISTANCE TO IMPROVE STUDENTS' UNDERSTANDING TOWARD STATISTICS
}

\author{
Yuliana $^{1}$, Fery Firmansah ${ }^{2}$ \\ ${ }^{1,2}$ Widya Dharma University, Jalan Ki Hajar Dewantara, Klaten, Jawa Tengah, Indonesia \\ ${ }^{1}$ pakyulikids@unwdha.ac.id, ${ }^{2}$ feryfirmansah@unwidha.ac.id
}

Received: August 19, 2017 ; Accepted: July 06, 2018

\begin{abstract}
The objectives of the research are (1) to develop mathematics learning through Problem Based Learning (PBL) with social media assistance in improving students' understanding toward statistics and (2) to find out the effectiveness of PBL with social media assistance. This research is a quasiresearch with cluster random sampling. The cluster random sampling was employed to determine a control class and an experimental class. After treatment for each class, post-test was done. Then, the post-test data was analyzed through a T-test. The result is the mean score of post-test in experimental class was better than that in control class. It means PBL with social media assistance is more effective than the conventional model to teach statistics. The result was supported by a questionnaire that showed learning mathematics through PBL with social media assistance got a positive response from the students.
\end{abstract}

Keywords: PBL, social media assistance, conventional method, understanding toward statistics.

\begin{abstract}
Abstrak
Penelitian ini bertujuan untuk (1) mengembangkan model pembelajaran problem based learning berbantuan media sosial dalam meningkatkan pemahaman mahasiswa terhadap statistika dan (2) mengetahui efektivitas model pembelajaran problem based learning berbantuan media sosial. Dengan teknik kluster random sampling dalam pemilihan sampel terpilih satu kelas kontrol dan satu kelas eksperimen. Setelah diberikan perlakuan pada masing-masing kelas, diperoleh data post-test. Data post-test ini dianalisis menggunakan uji t. Rerata hasil post-test menunjukkan bahwa kelas eksperimen lebih tinggi dibandingkan rerata kelas kontrol. Dengan demikian berarti pembelajaran problem based learning berbantuan media sosial lebih efektif daripada model konvensional. Disamping itu, melalui angket menunjukkan bahwa pembelajaran problem based learning berbantuan media sosial ternyata juga mendapatkan respon positif dari mahasiswa.
\end{abstract}

Kata Kunci: problem based learning, media sosial, metode konvensional, pemahaman statistis.

How to Cite: Yuliana, Y., \& Firmansah, F. (2018). The Effectiveness of Problem-Based Learning with Social Media Assistance to Improve Students' Understanding Toward Statistics. Infinity, 7(2), 97-108. doi:10.22460/infinity.v7i2.p97-108. 


\section{INTRODUCTION}

The development of technology and information grows fast nowadays. It is indicated through the appearance of many social media (Gunduz, 2017), such as whatsapp, bbm, line, whechatt, telegram, etc. This phenomenon contributes positive effect in educational development, such as online learning via social media.

According to Stephenson (2001), online based learning has 4 main features, namely the use of social media for dialog and learning material as well, the support of online technology, students' authority in handling the learning process through task, learning result, or assessment. Online learning efficiency, effectiveness, and makes the students keep learning (Mitcell \& Honore, 2008).

Teaching and learning process will be easier to conduct. It can be conducted wherever and whenever without any time and place burden. Online discussion will be the best learning type since many people including college students use social media to communicate. Unfortunately, they haven't used social media to learn together including the students and the lecturers of Widya Dharma University.

The use of technology and information system is highly needed in understanding lecture material. For example, the existence of calculator, excel, and SPSS application really supports applied statistics learning. The applications do not only help in calculating the data, but also in displaying and analyzing the data.

In applied statistics, statistics methods are learnt. They are hypothesis test, analysis of variance, analysis of regression, and analysis correlation. The students should master them well especially when they are doing research. Therefore, applied statistics is a crucial subject to understand by the students of mathematics education program (Sungkono, Yuliana, \& Syaifuddin, 2014).

Applied statistics subject is still problem for the students of mathematics education program. It can be seen from the result of their applied statistics test in which there are more than $60 \%$ of students haven't passed the passing grade. Besides, the result of interview for the students who are doing thesis indicates that the students haven't mastered statistics material for their research.

Moreover, the students said that statistics subject is not impressing subject for them. On the other words, they cannot tell what they have learnt about. They couldn't correlate statistics with their daily life. Besides, their skill and understanding in using statistics is low. They study statistics only from the lecturer without any further discussion with their friends. The learning process is teacher-centered so the students feel uncomfortable to ask questions. Consequently, their understanding is just partial and they couldn't apply statistics in their research well.

Nowadays, there are many innovative and active teaching methods. Innovative teaching methods can effectively improve students' learning achievement (Yuliana, Tasari, \& Wijayanti, 2017; Sethi, Sethi, \& Jeyaraj, 2017). The methods can be implemented appropriately based on the need of the class. Besides, the development of technology and information grows fast. It can be used to support student learning process. Learning doesn't absolutely need a meeting in a room. But, it can be conducted in different places. 
Many college students use gadgets even they follow the trend. This phenomenon is a kind of benefit in learning process (Nawi, Hamzah, Ren, \& Tamuri, 2015). The students will learn better if they learn something near to them. Learning method that is based on the problem will engage them to think critically. The technology-based learning and problem-based learning will well collaborated in learning process. Research about the use of latest information technology was done by Naidoo \& Kopung (2016). It used social media whatsapp to develop mathematics learning. Moreover, Yuwono \& Syaifuddin (2017) collaborated PBL and smartphone media to teach mathematics.

Problem Based Learning is a learning method that involves students to solve the problem. The steps of this method (Rubiah, 2016) are (1) appearing a problem and ensuring that the problem is contextual; (2) organizing the subject toward the problem; (3) giving the students responsibility to conduct the learning process; (4) making small groups; (5) asking the students to present what they have learnt. Problem Based Learning (PBL) has a crucial role for the students in the process of exploring important and meaningful questions, investigating a problem solution, and developing a deep-integrated understanding of content and process (Frank, Lavy, \& Elata, 2003; Hmelo-Silver, 2004).

In this research, researcher is interested to combine PBL with social media whatsapp in teaching mathematics. The teaching steps are (1) the lecturer makes a whatsapp grup discussion. The member is all students. (2) The use of whatsapp eases the lecturer to deliver the learning objectives and lesson plan to the students. (3) The students then can explore the learning materials from any references. (4) To motivate the students, some materials are shared in the group by the lecturer. (5) The lecturer also gives some tasks to accomplish. (6) Then, the students discuss in the group. The role of lecturer here is helping the students in organizing the task, motivating the students to collect related information, testing, and solving the problem. Moreover, the lecturer helps the students in preparing their findings report. (7) Later on, the result is presented in front of the class.

Social media that is used in the research is whatsapp. It is collaborated with Problem Based Learning (Hmelo-Silver \& Borrow, 2006). The students make a group discussion by whatsapp. They can get information about lesson plan, learning material, and problem discussion. The discussion can be conducted everywhere and every time. They don't need to wait until class meeting. Problem Based Learning with social media assistance emphasizes on the process of learning. It is reflected by keeping the students active. In accordance with Ningsih \& Rohana (2016), learning which accentuates more on the process is meaningful for learner.

The reality of the students' condition about their understanding toward statistics subject and the technology and information development motivates the teacher to do research about how to find the most effective way of teaching to improve students' understanding toward statistics material by PBL with social media assistance. The understanding toward the material can be identified through the learning result after joining the class.

\section{METHOD}

Students of mathematics education program are the subject of this research. By employing cluster random sampling, control and experimental class are determined. Control class is 21 students taught using conventional method, while experimental class is 18 students treated 
using problem based learning with social media assistance. The illustration of PBL learning steps with social media assistance can be seen as follows:

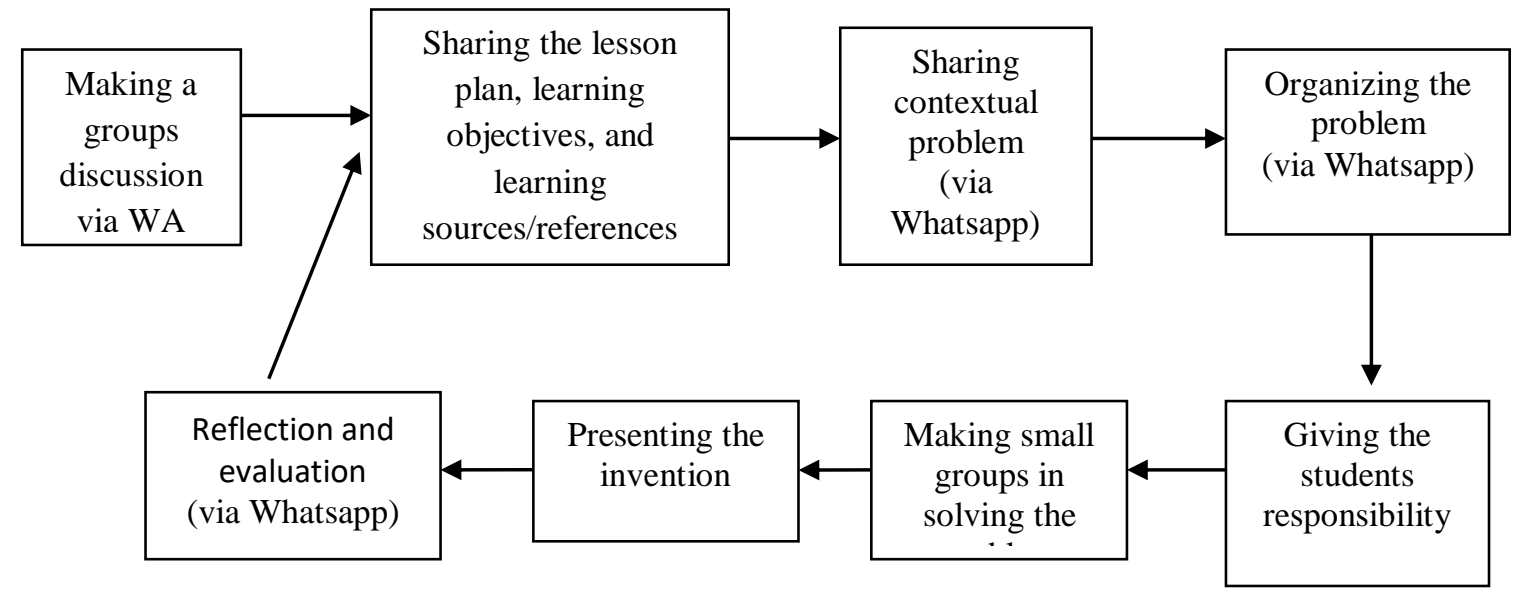

Figure 1. The illustration of PBL learning steps with social media assistance

The research uses documentation method, questionnaire method, and test method to collect the data. The documentation method is used to identify the problem. The questionnaire method is used to know students' responses toward the learning process. The questionnaire method is used to measure the validity of the instrument as well. The statement of questionnaire consists of two alternative answers: yes and no (Yogesh, 2006).

To know the students' response toward the use of Problem Based Learning with social media assitance, questionairre is distributed in experimental class. There are 16 statements that have been validated by 3 validators. The result of validity test from the three validators state that the questionairre could be used for the research.

By three collecting data techniques above, data is gotten. Then, they are classified as qualitative and quantitative data. Qualitative data involves lesson plan, teaching material, test items, and questionnaire. Meanwhile, quantitative data is the score of pre-test and post-test.

The result of pre-test is used to know the early condition before treatment for both control and experimental class. The students' understanding after treatment is measured through post-test. The result of pre-test and post-test is analyzed by using T-test with significant $\alpha=0.05$ and 95\% confidence interval (Keselman, Othman, Wilcox, \& Fradette, 2004). Lilliefors method is used to do normality test as prerequisite test of T-test (Usman, 2016). Meanwhile, homogeneity test uses comparison of 2 variances is F-test (Yuan \& Bentler, 1999). All computation in the analysis was done through SPSS for windows computer application (Chatfield, 1995; Pallant, 2010).

\section{RESULTS AND DISCUSSION}

\section{Results}

Learning documents that are developed in the class are syllabus, lesson plan, learning material, learning media, and test items. The instruments are validated by three experts judgment and its result is the learning documents can be used in the research. The lecturer's and students'activity during the learning process is described in Table 1. 
Table 1. The lecturer's and students'activity during the learning process in experimental class

Phase

\section{Phase 1}

Students orientation towards the problems

\section{Phase 2}

Organizing the students

\section{Phase 3}

Guiding individual's research and group

\section{Phase 4}

Developing and serving the report

\section{Phase 5}

Analyzing and evaluating the process of problem solving

\section{The lecturer activities}

- Explaining the learning objectives

- Sharing the learning sources

- Motivating the students to actively involve in solving the problem

Helping organize the problem

Encouraging the students to collect information and problem solving method

- Helping the students prepare the report

- Encouraging the students to distribute the task and work together

Evaluating the learning result and asking the groups to present their report

Before treatment, each class was given pre-test. The result of pre-test can be seen in Table 2 as follows.

Table 2. The Students' Pre-test Data

\begin{tabular}{lcc}
\hline & Experiment Class & Control Class \\
\hline The students & 18 & 21 \\
Maximum & 88 & 85 \\
Minimum & 30 & 49 \\
Mean & 62.61 & 65.05 \\
Standard deviation & 15.996 & 10.45 \\
The score more than 60 & $55.56 \%$ & $66.67 \%$ \\
\hline
\end{tabular}

Based on the pre-test data, maximum score and average score are high. Nevetheless, the percentage of students in both experimental and control class which is more than 60 is $55.56 \%$ and $66.67 \%$.

Pre-test data on Table 1 is analyzed its homogeneity and normality. The result of F-test is $\mathrm{p}$ value $=0.054$. It is more than significant $(\alpha) 0.05$. It means that the data is homogenious. Meanwhile, the result of test is $p$ value 0.146 for experimental class and 0.20 for control class. The $\mathrm{P}$ value from eachclass is more than significant 0.05 . It means, each class is normal.

Two prerequisite tests are fullfilled. Therefore, T-test can be conducted. The result can be seen on Table 3. 
Table 3. The Result of T-Test for Pre-test

\begin{tabular}{|c|c|c|c|c|c|c|c|}
\hline & $\mathbf{T}$ & DF & P Value & $\begin{array}{c}\text { Mean } \\
\text { difference }\end{array}$ & $\begin{array}{l}\text { Standard } \\
\text { Error Dif }\end{array}$ & $\begin{array}{l}\text { Lower } \\
\text { Bound }\end{array}$ & $\begin{array}{l}\text { Upper } \\
\text { Bound }\end{array}$ \\
\hline $\begin{array}{l}\text { Equal variances } \\
\text { assumed }\end{array}$ & 0.571 & 37 & 0.572 & 2.437 & 4.269 & -6.213 & 11.086 \\
\hline $\begin{array}{l}\text { Equal variances not } \\
\text { assumed }\end{array}$ & 0.553 & 28.477 & 0.585 & 2.437 & 4.407 & -6.583 & 11.456 \\
\hline
\end{tabular}

The result of test is p value 0.572 more than significant 0.05 . It means, both classes have same capability before treatment.

Having identified the early condition of control class and experimental class, both classes were given treatment. Each class was given 10 meetings. Then, both classes were measured its capability using test. The data description of post-test is shown in Table 4.

Table 4. The Students' Post-test Data

\begin{tabular}{lcc}
\hline & Experimental Class & Control Class \\
\hline The students & 18 & 21 \\
Maximum & 85 & 85 \\
Minimum & 30 & 25 \\
Mean & 61 & 48.57 \\
Standard deviation & 13.09 & 17.13 \\
The score more than 60 & $72.22 \%$ & $19.05 \%$ \\
\hline
\end{tabular}

Based on the data on Table 2 and Table 4, the average score of pre-test is higher than the average score of post test. The coverage material of pre-test and post-test is a little bit different. The material of post-test is wider than that of pre-test. It is the factor why the average score of pre-test is higher than the average score of post-test. In experimental class, the students who get score more than 60 is $72.22 \%$. It is categorized as high improvement. It contras, It is only $19.05 \%$ who get more than 60 in control class.

Based on the result of pre-test and post-test, there isi decrease for the mean score in both experimental class and control class. However, there is an increase $16.66 \%$ for the students who get more than 60 in experimental class. If the score 60 is used as passing grade so there are 13 students who can pass it and only 5 students who get under it. In contrast, there only 4 students can pass the passing grade and 17 students fail to achieve it. It shows there is a decrease for control class. The data describes the result of post-test in experimental class better than the result fo pre-test. Moreover, the post test score in experimental class is better than that in control class.

Post-test data in Table 4 is analyzed its homogeneity and normality. The result of $F$ test is $p$ value $=0.161$. It is more than significant $(\alpha) 0.05$. It means that the data has the same variance or the data is homogeneous. Meanwhile, the result of Lilliefors test is $p$ value 0.096 for experimental class and 0.200 for control class. $\mathrm{P}$ value for both classes is more than significant 0.05 . It means both class are normal. 
The prerequisite test has been fulfilled. Then, to identify the efectiveness of teaching method, T-test two tails is carried out. The result of T-test is $p$ value 0.019 and the mean score different between control class and experimental class is 12.5 . $\mathrm{P}$ value is less than significant 0.05. It mean there is difference between the students taught using Problem Based Learning with social media assistance and those who are taught using conventional method. The value of difference is positive. It means the learning result of experimental class is better than control class. In summary, Problem Based Learning with social media assistance is more effective to teach statistics than conventional method. The result can be seen in Table 5 .

Table 5. The result of T-test for Post-test

\begin{tabular}{lccccccc}
\hline & T & DF & P Value & $\begin{array}{c}\text { Mean } \\
\text { difference }\end{array}$ & $\begin{array}{c}\text { Standard } \\
\text { Error Dif }\end{array}$ & $\begin{array}{c}\text { Lower } \\
\text { Bound }\end{array}$ & $\begin{array}{c}\text { Upper } \\
\text { Bound }\end{array}$ \\
\hline $\begin{array}{l}\text { Equal variances } \\
\text { assumed }\end{array}$ & 2.511 & 37 & 0.017 & 12.429 & 4.949 & 2.401 & 22.456 \\
$\begin{array}{l}\text { Equal variances not } \\
\text { assumed }\end{array}$ & 2.564 & 36.564 & 0.015 & 12.429 & 4.847 & 2.603 & 22.254 \\
\hline
\end{tabular}

Based on the result of T-test, $\mathrm{p}$ value is 0.017 . The difference mean of post-test score between experimental class and control class is 12.429 . The result of $p$ value is less than significant $(\alpha)$ 0.05. It means, there is difference of learning achievement for the class that is taught using Problem Based Learning with social media assistance and that is taught using conventional method. The mean difference of learning achievement between experimental class and control class is positive so the learning achievement of experimental class is better than control class.

Based on the pre-test score, the students' ability in both classes is in the same level. Later on, the experimental class was taught by Problem Based Learning with Social Media Assistance. The post-test score of experimental class shows that the students' understanding toward statistics is better than that of control class. It is supported by the percentage of minimal passsing grade on the data in Table 4. The percentage of minimal passing grade score in experimental class is better than that in control class. Based pre-test data and post-test data means that Problem Based Learning with social media assistance is more effective to teach statistics than conventional method. This statement is supported by students's reponse result throught questionairre.

The questionnaire has been stated valid and reliable so it is ready to use in the research. The result is $61 \%$ items get positive response from the students. The percentage of each item is more than $80 \%$. It means Problem Based Learning with social media assistance can improve students' interest in joining lecture.

\section{Discussion}

In experimental class, the students are taught using PBL with social media assistance. First, whatsapp group discussion is made. This group will encourage the students to intensively communicate with other students and the students with the lecturer as well (Hrastinski, 2009). Communication between the students in experimental class runs better than that in control class. Besides, the use of whatsapp lets the students efficiently communicate in sharing knowledge and information (Hamzah, 2015; Kartikawati \& Pratama, 2017; Bouhnik \& Deshen, 2014). The material that is distributed by the lecturer and the students through whatsapp can be received fast by the students without any time and place burden. This kind of 
knowledge sharing is better than in control class. Control class receives knowledge and information just in lecture time.

In experimental class, the students are divided into some small groups so that the lecturer can focus on the learning management (Nicholl \& Lou, 2012). PBL with social media assistance method lets the students study in small groups that takes place outside in the classroom. Each group discusses to solve problem. The researcher modify the learning process of PBL to avoid boredom. In line with Lee \& Bae (2008) state the one of factors that determines the success of PBL is modifying it.

The conclusion of the research is in line with the research that was done by Padmavathy \& Mareesh (2013). It is the implementation of Problem Based Learning with social media assistance to increase students' motivation and interest to learn statistics. So the students have better understanding toward statistics.

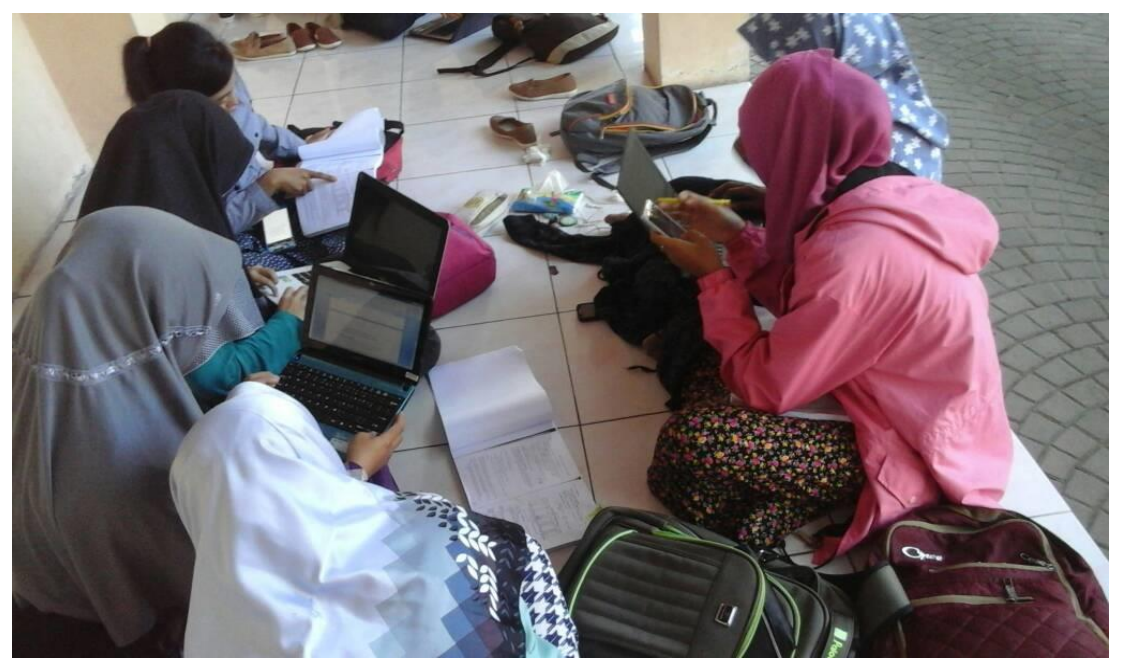

Figure 2. The students are discussing learning material in group

The role of teacher in class tends to be facilitator in which he/she just ensures that the students learn something and help the students when they need it. The teacher gives some real life problems (Botty et al, 2016) through questions, teamwork, and how to come to its answer. Students work in small groups of three or four people. In the group, the students present their discussion result. The students also learn how to make a conceptual knowledge not only theory memorization (Mustaffa et al, 2014). It makes statistics more impressing for the students. As the consequence, their understanding is better. It can be seen from the result of their statistics test. 


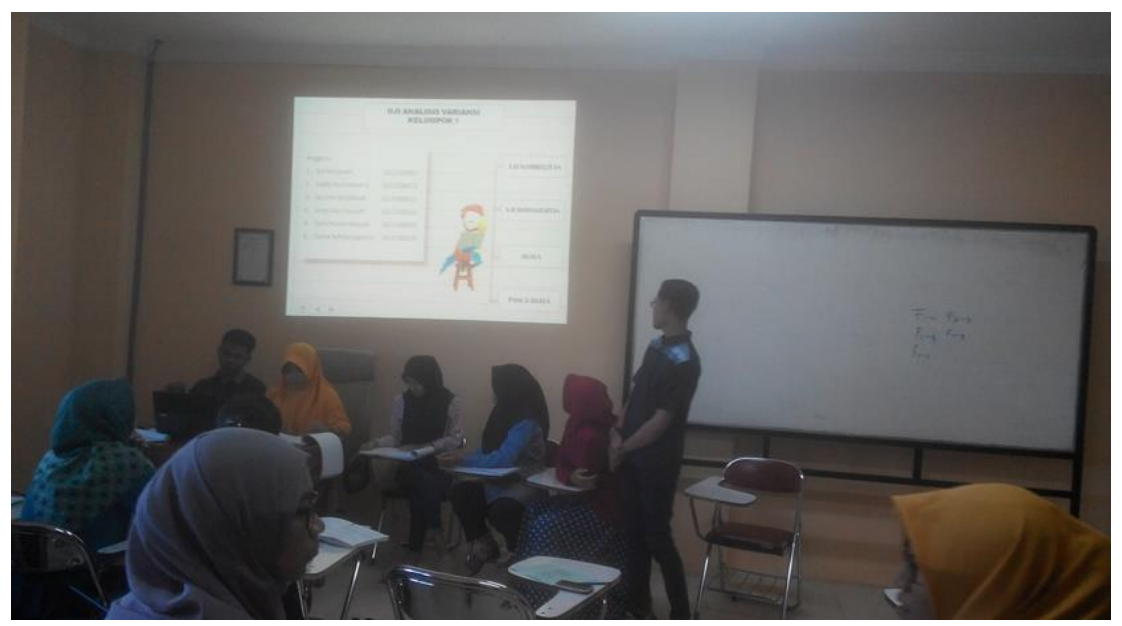

Figure 3. The student is presenting discussion result

The benefits of Problem Based Learning with social media assistance to teach statistics show that this method is more effective than conventional method. The same conclusion is written by Kazemi \& Ghoraishi (2012). It can be seen from the result of post test with T-test analysis. The result of T-test two tails is p value equals to 0.019, while the mean difference of post test in experimental class and control class is 12.5 . $\mathrm{P}$ value is less than significant 0.05 . It means there is difference learning result between experimental class and control class. Because the difference value is positive, the conclusion the learning result of experimental class is better than control class. It is similar with research conclusion carried out by Kazemi \& Ghoraishi (2012).

\section{CONCLUSION}

In line with the validation result, Problem Based Learning with social media assistance that is developed by the researcher is implemented like how it is stated in lesson plan. The learning method also got positive response from the students. It can be seen by the result of questionnaire. In addition, the result of T-test shows that Problem Based Learning with social media assistance is more effective to teach statistics than conventional method.

\section{ACKNOWLEDGMENTS}

The research could be well accomplished because the support of Widya Dharma University. The research was funded by Technology Research and High Education Ministry in 2017 budgeting. The researcher thanks so much for the fund and support.

\section{REFERENCES}

Botty, H. M. R. H., Shahrill, M., Jaidin, J. H., Li, H. C., \& Chong, M. S. F. (2016). The implementation of problem-based learning (PBL) in a year 9 mathematics classroom: A study in Brunei Darussalam. International Research in Education, 4(2), 34-47.

Bouhnik, D., \& Deshen, M. (2014). WhatsApp Goes to School: Mobile Instant Messaging between Teachers and Students. Journal of Information Education Research, 13, 217-231.

Chatfield, C. (1995). Model Uncertainty, Data Mining, and Statistical Inference. JRSS-A, 158, 419-466. 
Frank, M., Lavy, I., \& Elata, D. (2003). Implementing the Project Based Learning Approach in an Academic Engineering Course. International Journal of Technology and Design Education, 13, 273-288.

Gunduz, G. (2017). The Effect of Social Media on Identity Construction. Mediterranean Journal of Social Sciences, 8(5). DOI: 10.1515/mjss-2017-0026.

Hamzah, R. E. (2015). Penggunaan Media Sosial di Kampus Dalam Mendukung Pembelajaran Pendidikan. Jurnal Wacana, XIV(1), 45-70.

Hmelo-Silver, C. E. (2004). Problem-based learning: What and how do students learn?. Educational psychology review, 16(3), 235-266.

Hmelo-Silver, C. E., \& Barrows, H. S. (2006). Goals and strategies of a problem-based learning facilitator. Interdisciplinary journal of problem-based learning, 1(1), 4.

Hrastinski, S. (2009). A Theory of Online Learning as Online Participation. Journal Computers and Education, 52(1), 78-82.

Kartikawati, S., \& Pratama, H. (2017). Pengaruh Penggunaan WhatsApp Messenger sebagai Mobile Learning Terintegrasi Metode Group Investigation Terhadap Kemampuan Berpikir Kritis. JUPITER (Jurnal Pendidikan Teknik Elektro), 2(2), 33-38.

Kazemi, F., \& Ghoraishi, M. (2012). Comparison of Problem-based Learning Approach and Traditional Teaching on Attitude, Misconceptions and Mathematics Performance of University Students. Procedia - Social and Behavioral Sciences, 46 (1), 3852 - 3856.

Keselman, H.J., Othman A.R., Wilcox, R.R., \& Fradette, K. (2004). The New and Improved Two-Sample $t$ Test. Journal of Educational and Behavioral Statistics, 15(1), 47-51. https://doi.org/10.1111/j.0963-7214.2004.01501008.x.

Lee, H., \& Bae, S. (2008). Issues in implementing a structured problem-based learning strategy in a volcano unit: A case study. International Journal of Science and Mathematics Education, 6(4), 655-676.

Mitchell, A., \& Honore, S. (2008). E-learning-Critical for Success-the Human Factor. United Kingdom: Ashridge Business School.

Mustaffa, N. B., Ismail, Z. B., Tasir, Z. B., \& Mohamad Said, M. N. H. B. (2014). ProblemBased Learning (PBL) in Mathematics: a Meta Analysis. In International Education Postgraduate Seminar 2014, p301.

Naidoo, J. \& Kopung, K. J. (2016). Exploring the use of WhatsApp in Mathematics Learning: A Case Study. Journal of Communication, 7(2), 266-273.

Nawi, A., Hamzah, M. I., Ren, C. C., \& Tamuri, A. H. (2015). Adoption of Mobile Technology for Teaching Preparation in Improving Teaching Quality of Teachers. International Journal of Instruction, 8(2), 113-124.

Nicholl, T. A., \& Lou, K. (2012). A Model for Small-Group Problem-Based Learning in a Large Class Facilitated by One Instructor. American Journal of Pharmaceutical education,76(2), 117-124. DOI: 10.5688/ajpe766117

Ningsih, Y. L., \& Rohana, R. (2016). Prospective Teachers' Ability in Mathematical Problem-Solving through Reflective Learning. Infinity Journal, 5(2), 75-82.

Padmavathy \& Mareesh, K. (2013). Effectiveness of Problem Based Learning In Mathematics. International Multidisciplinary, II(1) 45-51. 
Pallant, J. (2010). SPSS survival Manual: a Step by Step Guide to Data Analysis Using SPSS for Windows (3rd ed.). Maidenhead: Open University Press.

Rubiah, M. (2016). Implementation of Problem Based Learning Model in Concept Learning Mushroom as a Result of Student Learning Improvement Efforts Guidelines for Teachers. Journal of Education and Practice, 22(7), 26-30.

Sethi, V., Sethi V., \& Jeyaraj, A. (2017). Enabling Context-based Learning with KPortal Webspace Technology. The Journal of Effective Teaching, 17(3), 38-58.

Stephenson, J. (2001). Teaching \& Learning Online: Pedagogies for New Technologies. Stylus Publishing, Inc., 22883 Quicksilver Dr., Sterling, VA 20166-2012.

Sungkono, J., Yuliana, \& Syaifuddin, M.W. (2014). Uji Efektifitas Strategi Pembelajaran Info Search Berbasis Pembelajaran Matematika Realistik (PMR) Pada Mata Kuliah Statistika Dasar 2. Jurnal MAGISTRA, 26(90), 28-36.

Usman, M. (2016). On Consistency and Limitation of Independent t-test Kolmogorov Smirnov Test and Mann Whitney U test. IOSR Journal of Mathematics, 12(4), 22-27.

Yogesh, K. S. (2006). Fundamental of Research Methodology and Statistics. New Delhi : New Age Internasional.

Yuan, K. H. \& Bentler, P.M. (1999). Tests for Mean and Covariance Structure Analysis. Journal of Educational and Behavioral Statistics, 24(3), 225-243. https://doi.org/10.3102/10769986024003225.

Yuliana, Y., Tasari, T., \& Wijayanti, S. (2017). The Effectiveness Of Guided Discovery Learning To Teach Integral Calculus For The Mathematics Students Of Mathematics Education Widya Dharma University. Infinity Journal, 6(1), 01-10.

Yuwono, M. R., \& Syaifuddin, M. W. (2017). Pengembangan problem based learning dengan assessment for learning berbantuan smartphone dalam pembelajaran matematika. Beta Jurnal Tadris Matematika, 10(2), 184-202.

Zancul, E. D. S., Sousa-Zomer, T. T., \& Cauchick-Miguel, P. A. (2017). Project-based learning approach: improvements of an undergraduate course in new product development. Production, 27(SPE). 
108 Yuliana, \& Firmansah, The Effectiveness of Problem-Based Learning with Social Media ... 